\title{
Effect of Composition and Morphology on Sensor Properties of Aerosol Deposited Nanostructured $\mathrm{ZnO}+\mathrm{In}_{2} \mathrm{O}_{3}$ Films
}

\author{
Leonid I. Trakhtenberg1,2, Seyed M. Navid Khatami³, Genrikh N. Gerasimov'1, \\ Olusegun J. Ilegbusi ${ }^{3^{*}}$ \\ ${ }^{1}$ Semenov Institute of Chemical Physics, Russian Academy of Sciences, Moscow, Russia \\ ${ }^{2}$ Moscow Institute of Physics and Technology (State University), Moscow, Russia \\ ${ }^{3}$ Department of Mechanical and Aerospace Engineering, University of Central Florida, \\ Orlando, FL, USA \\ Email: ${ }^{*}$ ilegbusi@ucf.edu
}

Received 11 February 2015; accepted 3 March 2015; published 9 March 2015

Copyright @ 2015 by authors and Scientific Research Publishing Inc.

This work is licensed under the Creative Commons Attribution International License (CC BY).

http://creativecommons.org/licenses/by/4.0/

(c) (i) Open Access

\section{Abstract}

The structural characteristics are investigated of nanoheterogeneous films comprising $\mathrm{ZnO}, \operatorname{In}_{2} \mathrm{O}_{3}$ and $\mathrm{ZnO}+\mathrm{In}_{2} \mathrm{O}_{3}$ composite produced by aerosol spray pyrolysis technique (SPT). The process utilizes water solutions of zinc chloride and indium nitrate precursors. The $\mathrm{X}$-ray diffraction data show that the SPT process results in polycrystalline films of hexagonal wurtzite type $\mathrm{ZnO}$, and $\mathrm{In}_{2} \mathrm{O}_{3}$ crystals of cubic structure. SPT-synthesized $\mathrm{ZnO}+\mathrm{In}_{2} \mathrm{O}_{3}$ composites contain mixtures of these crystals. The morphology of the synthesized films is studied by scanning electron microscopy as well as the dependence of morphology on the synthesis conditions, specifically the temperature of the aerosol precipitation and the concentration of the precursors in solutions. The characteristics of nucleation and growth of oxide crystals during the synthesis of $\mathrm{ZnO}+\operatorname{In}_{2} \mathrm{O}_{3}$ composite films are also considered. The film with the composition $25 \mathrm{wt} \% \mathrm{ZnO}+75 \mathrm{wt} \% \mathrm{In}_{2} \mathrm{O}_{3}$ contains a large number of small crystal aggregates of arbitrary shape with a high density of contacts between the aggregates and are characterized by a homogeneous structure with high dispersion. Such morphology has high specific surface, which favors high sensory response. In addition, in this range of aggregate composition the relationship between the particles of the catalytically active component-ZnO, cleavage of hydrogen molecule, and $\operatorname{In}_{2} \mathrm{O}_{3}$ particles with a high concentration of conduction electrons is close to optimal for the maximum sensory effect in the detection of hydrogen.

\section{Keywords}

Nanoheterogenous Films, Nanocomposite Films, Mixed Metal Oxide Films, Aerosol Deposition,

\footnotetext{
*Corresponding author.
}

How to cite this paper: Trakhtenberg, L.I., Khatami, S.M.N., Gerasimov, G.N. and Ilegbusi, O.J. (2015) Effect of Composition and Morphology on Sensor Properties of Aerosol Deposited Nanostructured $\mathrm{ZnO}+\ln _{2} \mathrm{O}_{3}$ Films. Materials Sciences and Applications, 6, 220-227. http://dx.doi.org/10.4236/msa.2015.63026 


\section{Spray Pyrolysis}

\section{Introduction}

Metal oxide semiconductor films are widely applied in gas sensors. The properties of such sensors including sensitivity, selectivity and response time depend critically on the film microstructure [1]. The structure in turn is largely determined by the synthesis. Such films are usually synthesized by a variety of techniques including Spray Pyrolysis Technique (SPT) [2], sol-gel technique [3], and chemical vapor deposition [4].

A number of studies have shown that one promising approach to improve conductometric metal oxide sensors is to utilize semiconducting nanostructured composite materials consisting of metal oxides with different electronic structure and chemical properties [5]-[7]. It has been established that using a mixture of metal oxides, the resulting composite sensor material can achieve selectivity and sensitivity for gas detection in air ambience that far exceed those achievable with the individual constituent metal oxides of the composite [8]-[12].

Studies of sensory phenomena in metal oxide composites have shown that there are certain optimum compositions for which these effects reach maximum values [9] [10]. One of the important factors that determine the dependence of sensory phenomena in metal oxide composites on composition is the effect of composition on the morphology of the sensor film. Therefore, it is important to clarify the morphological features of the composite sensors that exhibit high sensitivity. These features depend on the nature of the components of the mixed metal oxide composite and the processing conditions.

Of particular interest are composite sensor films processed by SPT due to the inherent advantages of the technique, including ease of control, low cost, and simplicity [13] [14]. The present study focuses on SPT-synthesized composite films of $\mathrm{ZnO}+\mathrm{In}_{2} \mathrm{O}_{3}$ and comparison with similar films of $\mathrm{ZnO}$ and $\operatorname{In}_{2} \mathrm{O}_{3}$. It also relatesthe morphology of the $\mathrm{ZnO}+\mathrm{In}_{2} \mathrm{O}_{3}$ composite films to the sensor response.

\section{Experimental Setup and Procedure}

Water solutions of zinc chloride and indium nitrate were used to deposit $\mathrm{ZnO}$ and $\mathrm{In}_{2} \mathrm{O}_{3}$ films by SPT. The ZnO + $\mathrm{In}_{2} \mathrm{O}_{3}$ composites were synthesized by deposition of mixed solutions of different ratios between the concentrations (C) of the zinc chloride and indium nitrate precursors. The underlying chemical reactions of the SPT deposition can be expressed thus [15]:

$$
\begin{gathered}
\mathrm{ZnCl}_{2}+\mathrm{H}_{2} \mathrm{O} \rightarrow \mathrm{ZnO}+2 \mathrm{HCl}_{(\mathrm{g})} \\
2 \mathrm{In}\left(\mathrm{NO}_{3}\right)_{3}+3 \mathrm{H}_{2} \mathrm{O} \rightarrow \mathrm{In}_{2} \mathrm{O}_{3}+6 \mathrm{H}\left(\mathrm{NO}_{3}\right) .
\end{gathered}
$$

The SPT setup utilized is illustrated in Figure 1 [16]. A precursor solution which contains the constituent reactant compounds is atomized in a nozzle to tiny droplets which are then sprayed onto a preheated alumina substrate. The solutions are injected through a $1 \mathrm{~mm}$-diameter round spray needle and then atomized at 1 bar air pressure [17]. It is important that the temperature of the substrate be maintained within a range that can initiate chemical reaction in the droplet. The droplet also must still contain enough reactants in solution after reaching the surface [18]. A film of stable compounds subsequently forms and adheres to the substrate due to chemical reaction and thermal decomposition of the solution.

The distance between the spray nozzle and the hot surface is kept constant at $10 \mathrm{~cm}$ during the experiments. This distance was chosen based on the results of a previous study [16] [19]. Finally, the thin film is annealed for 30 minutes after deposition to the desired structures at $450^{\circ} \mathrm{C}$. The annealing process promotes adhesion of the film to the substrate. These conditions are kept constant for all other sets of experiments performed.

\section{Morphology of Aerosol Deposited Sensor Films}

The XRD patterns indicate that the SPT-synthesized ZnO films exhibit a polycrystalline hexagonal wurtzite structure while $\mathrm{In}_{2} \mathrm{O}_{3}$ films have a polycrystalline cubic structure [10]. The XRD data also indicate that SPTsynthesized $\mathrm{ZnO}+\mathrm{In}_{2} \mathrm{O}_{3}$ composites consist of mixtures of these crystal structures.

The deposited thin films were also characterized by Scanning electron microscopy (SEM). Specifically, the 
surface morphology was characterized using a Zeiss ULTRA-55 FEG SEM system which used Schottky field emission source and STEM detector. The ZnO films were synthesized at different temperatures. Figure 2 shows the SEM results at $350^{\circ} \mathrm{C}$ indicating that at this temperature several small spherical particles are formed and agglomerate at the surface in the shape of powders with an average size of about $50 \mathrm{~nm}$.

Keeping the concentration constant and increasing the deposition temperature, the results (not shown) indicate that dense $\mathrm{ZnO}$ oxide film is synthesized by the aerosol deposition at $400^{\circ} \mathrm{C}$. A further increase in temperature to $450^{\circ} \mathrm{C}$ increases the film uniformity, but reduces its specific surface area which can adversely affect the sensor response of the film.

Figure 3 shows the SEM micrographs of $\mathrm{ZnO}$ thin films synthesized at $\mathrm{C}=0.2 \mathrm{~mol} / \mathrm{lit}$ and $\mathrm{C}=0.3 \mathrm{~mol} / \mathrm{lit}$. The results show that the grain size of the $\mathrm{ZnO}$ film increases with increase in the amount of precursor dissolved in solution.

The SEM micrograph for $\mathrm{In}_{2} \mathrm{O}_{3}$ thin films deposited on $\mathrm{Al}_{2} \mathrm{O}_{3}$ by SPT at $400^{\circ} \mathrm{C}$ and precursor concentration $\mathrm{C}=$ $0.3 \mathrm{~mol} / \mathrm{lit}$ is presented in Figure 4. It is evident that the particles of both the $\mathrm{ZnO}$ film shown in a previous Figure 3(b), as well as similar particlesof the SPT-synthesized $\operatorname{In}_{2} \mathrm{O}_{3}$ film (Figure 4) are not separate crystallites, but are splices or aggregates of crystallites. An analogous structure has been observed for the particles of $\mathrm{SnO}_{2}-$ based nanoheterogeneous film in a previous study [20].

Thus, there are interparticle contacts of two types in the synthesized films: contacts between crystallites inside crystalline aggregates and contacts between aggregates. The contacts between aggregates of crystallites largely determine the conductivity of the nanocrystalline film [20].

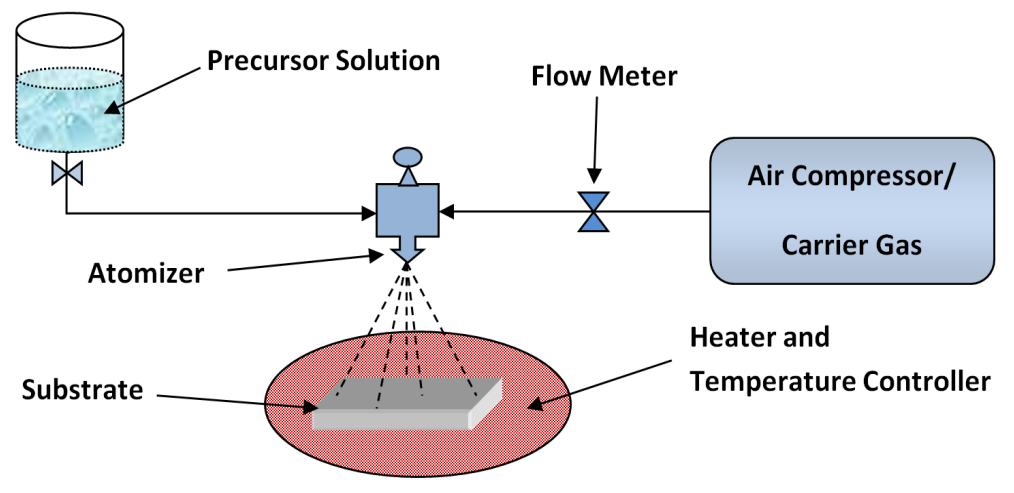

Figure 1. Schematic sketch of chemical spray pyrolysis process.

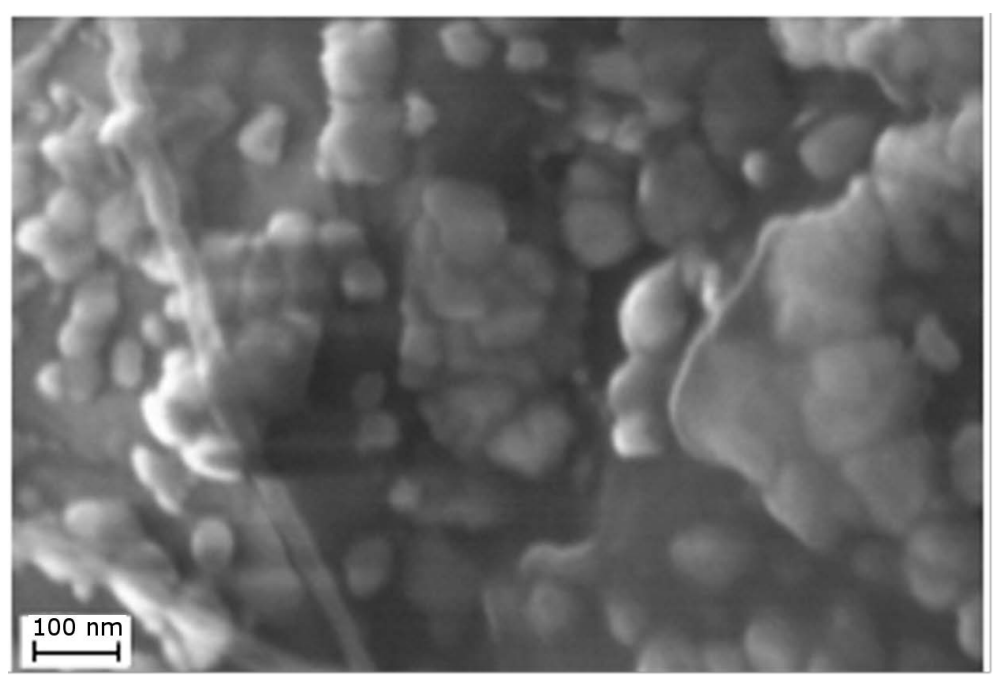

Figure 2. SEM micrographs of $\mathrm{ZnO}$ thin films synthesized by spray pyrolysis on $\mathrm{Al}_{2} \mathrm{O}_{3}$ substrate at $350^{\circ} \mathrm{C}$ and precursor solution concentration $\mathrm{C}=0.1$ $\mathrm{mol} / \mathrm{lit}$. 


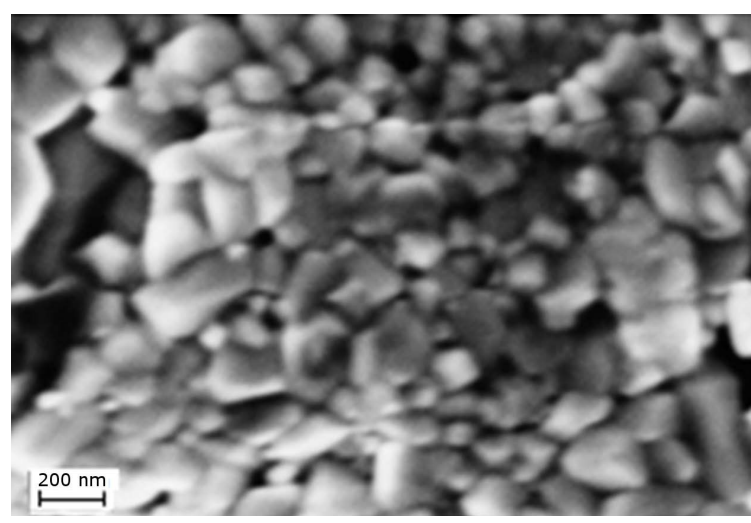

(a)

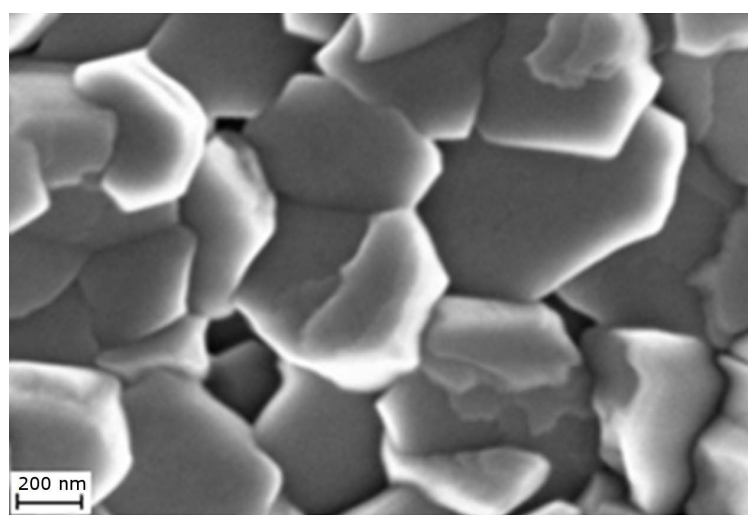

(b)

Figure 3. SEM micrographs of $\mathrm{ZnO}$ thin films on $\mathrm{Al}_{2} \mathrm{O}_{3}$ substrate at $\mathrm{T}=400^{\circ} \mathrm{C}$ and different concentrations of precursor: (a) $\mathrm{C}=0.2 \mathrm{~mol} / \mathrm{lit}$ and (b) $\mathrm{C}=0.3 \mathrm{~mol} / \mathrm{lit}$.

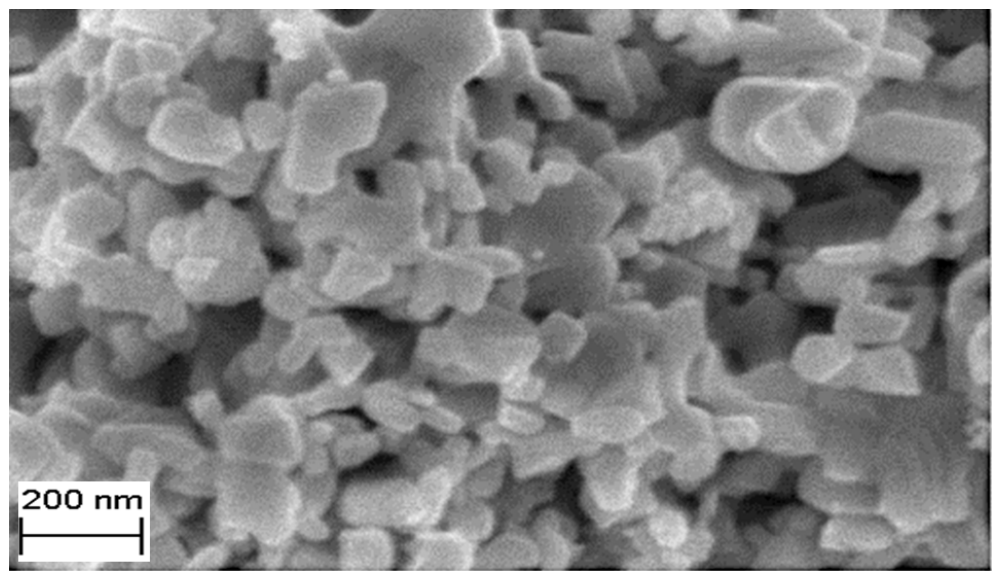

Figure 4. SEM micrographs of $\operatorname{In}_{2} \mathrm{O}_{3}$ thin films on $\mathrm{Al}_{2} \mathrm{O}_{3}$ substrate at $\mathrm{T}=$ $400^{\circ} \mathrm{C}$ and $\mathrm{C}=0.3 \mathrm{~mol} / \mathrm{lit}$.

Our study of SPT-processed $\mathrm{ZnO}+\mathrm{In}_{2} \mathrm{O}_{3}$ composite oxide films has demonstrated that the morphology of the films depends strongly on the composition. Figure 5 presents the photomicrographs of the composite films with various $\mathrm{ZnO}$ to $\mathrm{In}_{2} \mathrm{O}_{3}$ ratios. The composite film $0.25 \mathrm{ZnO}+0.75 \mathrm{In}_{2} \mathrm{O}_{3}$ (Figure 5(a)) consists of elongated particles of arbitrary shape, which are aggregates that combine small crystallites of $\mathrm{In}_{2} \mathrm{O}_{3}$ and $\mathrm{ZnO}$. The composite $0.8 \mathrm{ZnO}+0.2 \mathrm{In}_{2} \mathrm{O}_{3}$ (Figure 5(b)) contains for the most part faceted particles that are large individual $\mathrm{ZnO}$ crystals (or splices of such crystals).In this composite, such particles of $\mathrm{ZnO}$ are mixed with the $\mathrm{In}_{2} \mathrm{O}_{3}$ particles, which other studies [10] have shown to also increase the sensory response by about $15-20 \%$ compared to the response of pure $\mathrm{ZnO}$, i.e. considerably less than in the composite of Figure 5(a).

\section{Sensor Properties of Deposited Mixed Films}

As indicated above, the particles in the films considered are crystal aggregates, which in the case of the composite sensor consist of a mixture of nanocrystals of $\mathrm{In}_{2} \mathrm{O}_{3}$ and $\mathrm{ZnO}$ closely interacting with each other. In order to describe the sensor phenomenon, it is necessary to first consider the concentration of conduction electrons and the sensory effect in an isolated nanocrystal line aggregate of the film.

The conductivity of the isolated composite aggregate of $\mathrm{ZnO}+\operatorname{In}_{2} \mathrm{O}_{3}$ is determined by the $\operatorname{In}_{2} \mathrm{O}_{3}$ nanocrystals, since the concentration of conduction electrons in the $\mathrm{ZnO}$ crystals $\left(10^{16}-10^{17} \mathrm{~cm}^{-3}\right)$ [21] is three to four orders of magnitude lower than in the $\mathrm{In}_{2} \mathrm{O}_{3}$ crystals. The concentration of conduction electrons in the $\mathrm{In}_{2} \mathrm{O}_{3}$ crystals drops sharply under the influence of atmospheric oxygen, which is chemisorbed on the surface of the crystals, capturing electrons from the conduction band of $\mathrm{In}_{2} \mathrm{O}_{3}$ to form $\mathrm{O}^{-}$anion radicals [22]. Sensory response is mani- 


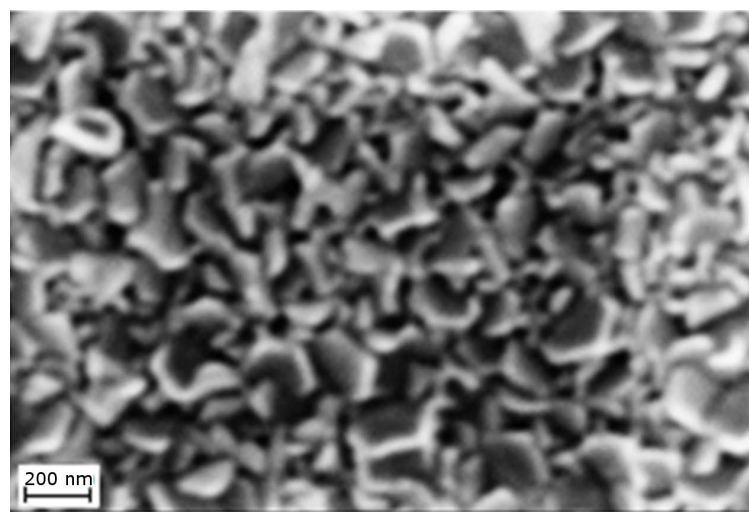

(a)

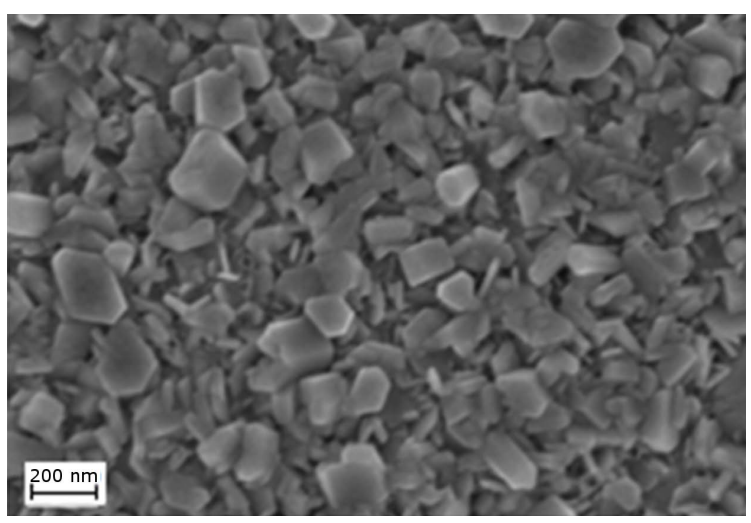

(b)

Figure 5. SEM micrographs of $\mathrm{ZnO}+\mathrm{In}_{2} \mathrm{O}_{3}$ thin films on $\mathrm{Al}_{2} \mathrm{O}_{3}$ substrate at ratios of (a) $0.25 \mathrm{ZnO}+0.75 \mathrm{In}_{2} \mathrm{O}_{3}$ and (b) $0.8 \mathrm{ZnO}+0.2 \mathrm{In}_{2} \mathrm{O}_{3}$ at $\mathrm{T}=400^{\circ} \mathrm{C}$ and total concentration of two precursors $0.1 \mathrm{~mol} / \mathrm{lit}$.

fested as an increase in conductivity due to the sensor reaction of the chemisorbed oxygen anions with hydrogen and the corresponding return of the electrons to the conduction band. The sensory reaction proceeds with participation of the $\mathrm{H}$ atoms [23], formed by the catalytic dissociation of molecular hydrogen.

A characteristic of the sensor response of $\mathrm{ZnO}+\mathrm{In}_{2} \mathrm{O}_{3}$ aggregates to hydrogen in air is that in these composite aggregates, the $\mathrm{In}_{2} \mathrm{O}_{3}$ nanocrystals having high concentration of the conduction electrons (about $10^{19}-10^{20} \mathrm{~cm}^{-3}$ ) [24], are in contact with the ZnOn anocrystals, which exhibit high catalytic activity in the reaction of hydrogen dissociation [25]. The contacts between $\mathrm{In}_{2} \mathrm{O}_{3}$ and $\mathrm{ZnO}$ crystals in a composite aggregate provide particularly favorable conditions for the sensor response of the aggregate to hydrogen in air: dissociation of hydrogen proceeds at the surface of the $\mathrm{ZnO}$ crystals with high catalytic cactivity in this reaction while the Hatoms formed on the surface of these crystal sreact with the $\mathrm{O}^{-}$onthesurfaceof $\operatorname{In}_{2} \mathrm{O}_{3}$ crystals, thereby increasing the concentration of conducting electrons in the aggregate.

The effect of $\mathrm{ZnO}$ on sensory response reaches a maximum value at $\mathrm{ZnO}$ composition of about $20 \%$, when almost all of the $\mathrm{In}_{2} \mathrm{O}_{3}$ crystallites are in contact with the $\mathrm{ZnO}$ crystallites [10]. The $0.25 \mathrm{ZnO}+0.75 \mathrm{In}_{2} \mathrm{O}_{3}$ composite film (Figure 5(a)) has demonstrated sensor response to hydrogen in air close to the maximum, which is 1.7 times the sensor response of pure $\mathrm{ZnO}$ films and 4 times the sensor response of pure $\operatorname{In}_{2} \mathrm{O}_{3}$ films [10]. A further increase in the composition of $\mathrm{ZnO}$ decreases the sensor response due to reduction of the concentration of conduction electrons in the $\mathrm{ZnO}+\mathrm{In}_{2} \mathrm{O}_{3}$ composite.

Under the influence of ambient hydrogen, the equilibrium concentration of conduction electrons inside the isolated $\mathrm{ZnO}+\mathrm{In}_{2} \mathrm{O}_{3}$ composite aggregate decreases much faster than the equilibrium concentration in the system of such units in contact. Therefore, the quasi-wire small aggregate shown in the previous Figure 5(a) can be considered as the basic structure and sensor unit of the film. The resistance and sensor response of the film depend on the characteristics of such units as well as on the density of contacts between the aggregates in the film [20]. These parameters therefore increase with decreasing size of aggregates and corresponding increase of their concentration in the film.

The crystallite sizes of $\mathrm{In}_{2} \mathrm{O}_{3}$ and $\mathrm{ZnO}$, as well as the size and shape of the aggregates formed from these crystallites are determined by the deposition of the film. It should be noted that the $\operatorname{In}_{2} \mathrm{O}_{3}$ crystallizes in the form of cubic crystals, which can have three types of cells that differ in the mutual arrangement of the atoms and the interatomic bonds [26]. The complexity of the $\mathrm{In}_{2} \mathrm{O}_{3}$ lattice influences the properties of the crystals (in particular, lattice thermal conductivity [27]) and hinders the growth of crystals during the deposition of $\operatorname{In}_{2} \mathrm{O}_{3}$ from aerosol. This explains the finding in a previous Figure 4 that SPT-synthesized $\operatorname{In}_{2} \mathrm{O}_{3}$ film comprises of splices of particles of arbitrary shape. In contrast, $\mathrm{ZnO}$ film consists of large-grained crystalline particles. It is also significant that in contrast to $\operatorname{In}_{2} \mathrm{O}_{3}, \mathrm{ZnO}$ crystallizes with a hexagonal structure [28], such that the interaction between these oxides during the SPT-deposition of $\mathrm{ZnO}+\mathrm{In}_{2} \mathrm{O}_{3}$ composite film should create additional hindrance to the growth of crystals.

As a result, the rate of nucleation may be greater than the rate of crystal growth. This may cause the formation of a large number of small crystals, which combine into the aggregates. Perhaps the nature of crystallization 
during deposition of $\mathrm{ZnO}+\mathrm{In}_{2} \mathrm{O}_{3}$ composite sensor films with a high composition of $\operatorname{In}_{2} \mathrm{O}_{3}$ is responsible for the formation of a large number of composite aggregates of small size, shown previously in Figure 5(a). The shape of these aggregates indicates deformation of aggregates in the course of their formation, which may also be explained by the hindrance to the growth of crystals in the composite. As shown in the photomicrographs of the composite films with various $\mathrm{ZnO}$ to $\mathrm{In}_{2} \mathrm{O}_{3}$ ratios (Figure 5), the composite films composed of $0.25 \mathrm{ZnO}+$ $0.75 \mathrm{In}_{2} \mathrm{O}_{3}$ besides their essential sensory properties [29], are characterized by a homogeneous dispersive structure with high specific surface. Thus, not only the electronic structure, but also the morphological properties of the film composition $0.25 \mathrm{ZnO}+0.75 \mathrm{In}_{2} \mathrm{O}_{3}$ with high density of contacts between crystal aggregates provides enhanced sensory effect in the detection of hydrogen in air ambience.

\section{Conclusions}

Three types of films comprising $\mathrm{ZnO}, \mathrm{In}_{2} \mathrm{O}_{3}$ and $\mathrm{ZnO}+\mathrm{In}_{2} \mathrm{O}_{3}$ composite were produced by spray pyrolysis technique (SPT) using water solutions of zinc chloride and indium nitrate precursor. The polycrystalline films obtained contain hexagonal wurtzite-type $\mathrm{ZnO}$ crystals and cubic $\mathrm{In}_{2} \mathrm{O}_{3}$ crystals. The study also considered the dependence of the morphology of the films on the synthesis conditions. It has been shown that increasing the deposition temperature in the range $350^{\circ} \mathrm{C}$ to $450^{\circ} \mathrm{C}$ results in the formation of films with more uniform particle sizes and the size of deposited particles increases with increasing concentration of precursor solution from 0.1 to $0.3 \mathrm{~mol} /$ /iter. The particles of the film are not separate crystallites, but splices or aggregates of crystallites. The interaction between crystallites inside crystalline aggregates is stronger that the interaction between aggregates. The conductivity of the film is determined by the electron density in an aggregate and the contacts between aggregates.

The morphology of the $\mathrm{ZnO}+\mathrm{In}_{2} \mathrm{O}_{3}$ composite films depends strongly on the composition of the film. It is shown that the film of composition $25 \mathrm{wt} \% \mathrm{ZnO}+75 \mathrm{wt} \% \mathrm{In}_{2} \mathrm{O}_{3}$ contains a large number of small crystal aggregates of arbitrary shape and therefore has a high density of contacts between the aggregates. It should be emphasized that only the films with good homogeneous structure demonstrated high sensory properties. In this range of aggregate composition, the relationship between the particles of the catalytically active component $(\mathrm{ZnO})$ that breaks hydrogen molecules and $\mathrm{In}_{2} \mathrm{O}_{3}$ particles with a high concentration of conduction electrons is close to optimal value. Therefore, due to both morphology and electronic structure of the films of this composition, the sensor response to hydrogen in air ambience is able to reach the maximal value.

\section{Acknowledgements}

The project was supported by the National Science Foundation under grant number CMMI-1030689 and the Russian Scientific Foundation grant No. 14-19-00781.

\section{References}

[1] Kruis, F.E., Fissan, H. and Peled, A. (1998) Synthesis of Nanoparticles in the Gas Phase for Electronic, Optical and Magnetic Applications-A Review. Journal of Aerosol Science, 29, 511-535. http://dx.doi.org/10.1016/S0021-8502(97)10032-5

[2] Perednis, D. and Gauckler, L.J. (2005) Thin Film Deposition Using Spray Pyrolysis. Journal of Electroceramics, 14, 103-111. http://dx.doi.org/10.1007/s10832-005-0870-x

[3] Kalantar-zadeh, K. and Fry, B. (2007) Nanotechnology-Enabled Sensors. Springer, New York.

[4] Perednis, D. (2003) Thin Film Deposition by Spray Pyrolysis and the Application in Solid Oxide Fuel Cells. Ph.D. Thesis, Swiss Federal Institute of Technology, Zurich.

[5] Trakhtenberg, L.I., Gerasimov, G.N., Gromov, V.F., Kozhushner, M.A. and Ilegbusi, O.J. (2012) Experimental Investigations and Modeling of Gas Sensing Effect in Mixed Metaloxidenanocomposites. In: Korotcenkov, G., Ed., Chemical Sensors: Simulation and Modeling, Momentum Press, New York, 261-296.

[6] de Lacy Costello, B.P.J., Ewen, R.J., Ratcliffe, N.M. and Sivanand, P.S. (2003) Thick Film Organic Vapour Sensors Based on Binary Mixtures of Metal Oxides. Sensors and Actuators B, 92, 159-166. http://dx.doi.org/10.1016/S0925-4005(03)00258-2

[7] Comini, E., Ferroni, M., Guidi, V., Faglia, G., Martinelli, G. and Sberveglieri, G. (2002) Nanostructured Mixed Oxides Compounds for Gas Sensing Applications. Sensors and Actuators B, 84, $26-32$.

http://dx.doi.org/10.1016/S0925-4005(02)00006-0 
[8] Kim, K., Cho, P., Kim, S., Lee, J., Kang, C., Kim, J. and Yoon, S. (2007) The Selective Detection of $\mathrm{C}_{2} \mathrm{H}_{5} \mathrm{OH} \mathrm{Using}$ $\mathrm{SnO}_{2}$-ZnO Thin Film Gas Sensors Prepared by Combinatorial Solution Deposition. Sensors and Actuators B, 123, 318324. http://dx.doi.org/10.1016/j.snb.2006.08.028

[9] Trakhtenberg, L.I., Gerasimov, G.N., Gromov, V.F., Belysheva, T.V. and Ilegbusi, O.J. (2012) Effect of Composition on Sensing Properties of $\mathrm{SnO}_{2}+\mathrm{In}_{2} \mathrm{O}_{3}$ Mixed Nanostructured Films. Sensors and Actuators B, 169, 32-38. http://dx.doi.org/10.1016/j.snb.2006.08.028

[10] Trakhtenberg, L.I., Gerasimov, G.N., Gromov, V.F., Belysheva, T.V. and Ilegbusi, O.J. (2013) Conductivity and Sensing Properties of $\operatorname{In}_{2} \mathrm{O}_{3}+\mathrm{ZnO}$ Mixed Nanostructured Films: Effect of Composition and Temperature. Sensors and Actuators B, 187, 514-521. http://dx.doi.org/10.1016/j.snb.2013.03.017

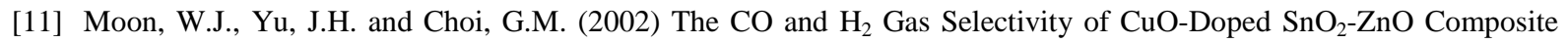
Gas Sensor. Sensors and Actuators B, 87, 464-470. http://dx.doi.org/10.1016/S0925-4005(02)00299-X

[12] Neri, G., Bonavita, A., Micali, G., Rizzo, G., Pinna, N., Niederberger, M. and Ba, J. (2008) Effect of the Chemical Composition on the Sensing Properties of $\mathrm{In}_{2} \mathrm{O}_{3}-\mathrm{SnO}_{2}$ Nanoparticles Synthesized by a Non-Aqueous Method. Sensors and Actuators B, 130, 222-230. http://dx.doi.org/10.1016/j.snb.2007.07.141

[13] Tofield, B.C. (1987) State of the Art and Future Prospects for Solid State Gas Sensors. In: Moseley, P.T. and Tofield, B.C., Eds., Solid State Gas Sensors, Adam Hilger, Bristol, 198-237.

[14] George, J. (1992) Preparation of Thin Films. CRC Press, New York, 339-342.

[15] Khatami, S.M.N., Ilegbusi, O.J. and Trakhtenberg, L.I. (2015) Mathematical Modeling and Experimental Validation of Mixed Metal Oxide Thin Film Deposition by Spray Pyrolysis. Materials Sciences and Applications, 6, 68-77. http://dx.doi.org/10.4236/msa.2015.61009

[16] Khatami, S.M.N. and Ilegbusi, O.J. (2011) Modeling of Aerosol Spray Characteristics for Synthesis of Mixed-Oxide Nanocomposite Sensor Film. Proceedings of the ASME 2011 International Mechanical Engineering Congress and Exposition, Denver, 11-17 November 2011, 581-589.

[17] Khatami, S.M.N., Kuruppumullage, D.N. and Ilegbusi, O.J. (2013) Characterization of Metal Oxide Sensor Thin Films Deposited by Spray Pyrolysis. Proceedings of the ASME 2013 International Mechanical Engineering Congress and Exposition, San Diego, 15-21 November 2013, V010T11A044-V010T11A044.

[18] Khatami, S.M.N. and Ilegbusi, O.J. (2012) Droplet Evaporation and Chemical Reaction in a Single Multi-Component Droplet to Synthesis Mixed-Oxide Film Using Spray Pyrolysis Method. Proceedings of the ASME 2012 International Mechanical Engineering Congress and Exposition, Houston, 9-15 November 2012, 633-638.

[19] Khatami, S.M.N., Ilegbusi, O.J. and Trakhtenberg, L. (2013) Modeling of Aerosol Spray Characteristics for Synthesis of Sensor Thin Film from Solution. Applied Mathematical Modelling, 37, 6389-6399.

http://dx.doi.org/10.1016/j.apm.2013.01.009

[20] Korotcenkov, G., Brinzari, V. and Boris, I. (2008) (Cu, Fe, Co, Or Ni)-Doped Tin Dioxide Films Deposited by Spray Pyrolysis: Doping Influence on Film Morphology. Journal of Materials Science, 43, 2761-2770. http://dx.doi.org/10.1007/s10853-008-2486-4

[21] Look, D.C., Farlow, G.C., Reunchan, P., Limpijumnong, S., Zhang, S.B. and Nordlund, K. (2005) Evidence for NativeDefect Donors in n-Type ZnO. Physical Review Letters, 95, Article ID: 225502. http://dx.doi.org/10.1103/PhysRevLett.95.225502

[22] Barsan, N. and Weimar, U. (2001) Conduction Model of Metal Oxide Gas Sensors. Journal of Electroceramics, 7, 143167. http://dx.doi.org/10.1023/A:1014405811371

[23] Kohl, D. (1989) Surface Processes in the Detection of Reducing Gases with $\mathrm{SnO}_{2}$-Based Devices. Sensors and Actuators B, 18, 71-133. http://dx.doi.org/10.1016/0250-6874(89)87026-X

[24] Jimenez, L.C., Mendez, H.A., Paez, B.A., Ramırez, M.E. and Rodriguez, H. (2006) Production and Characterization of Indium Oxide and Indium Nitride. Brazilian Journal of Physics, 36, 1017-1020. http://dx.doi.org/10.1590/S0103-97332006000600058

[25] Göpel, W., Rocker, G. and Feierabend, R. (1983) Intrinsic Defects of $\mathrm{TiO}_{2}$ : Interaction with Chemisorbed $\mathrm{O}_{2}, \mathrm{H}_{2}, \mathrm{CO}$ and $\mathrm{CO}_{2}$. Physical Review B, 28, 3427-3438. http://dx.doi.org/10.1103/PhysRevB.28.3427

[26] Karazhanov, S.Z., Ravindran, P., Vajeeston, P., Ulyashin, A., Finstad, T.G. and Fjellvag, H. (2007) Phase Stability, Electronic Structure, and Optical Properties of Indium Oxide Polytypes. Physical Review B, 76, Article ID: 075129. http://dx.doi.org/10.1103/PhysRevB.76.075129

[27] Brinzari, V., Damaskin, I., Trakhtenberg, L., Cho, B.K. and Korotcenkov, G. (2014) Thermoelectrical Properties of Spray Pyrolyzed Indium Oxide Thin Films Doped by Tin. Thin Solid Films, 552, 225-231. http://dx.doi.org/10.1016/j.tsf.2013.12.009

[28] Janotti, A. and Van de Walle, C.G. (2009) Fundamentals of Zinc Oxide as a Semiconductor. Reports on Progress in 
Physics, 72, Article ID: 126501. http://dx.doi.org/10.1088/0034-4885/72/12/126501

[29] Jimenez, V.M., Espinos, J.P. and Gonzalez-Elipe, A.R. (1999) Effect of Texture and Annealing Treatments in SnO ${ }_{2}$ and $\mathrm{Pd} / \mathrm{SnO}_{2}$ Gas Sensor Materials. Sensors and Actuators B, 61, 23-32.

http://dx.doi.org/10.1016/S0925-4005(99)00275-0 